Finisterra, XXXVII, 74, 2002, pp. 55-71

\title{
THE GEOGRAPHY OF “DISUSED” RAILWAYS: WHAT IS HAPPENING IN PORTUGAL? ${ }^{1}$
}

\author{
JoÃo SARMENTO ${ }^{2}$
}

\begin{abstract}
Greenways have been established for a number of years throughout the world. Recently the concept of Greenways has acquired a multifunctional dimension, and is now used by planners as a tool for preserving environmental qualities of the landscape, as well as to structure leisure resources. It has even become a significant part of transport planning in urban areas. This article focuses on the ways in which disused railways can be an integral part of greenway planning. Firstly, the greenway concept and its evolution will be approached. This will be followed by a brief summary of the railway history in Portugal and an analysis of the present situation in the country regarding railways that are not in use any more. Finally, a detailed study of the first cycleway built in Portugal by using the disused railways between Guimarães and Fafe in the Northwest of the country will be presented.
\end{abstract}

Key words : Greenways, Cycleways, Disused Railways, Transport and Leisure Planning.

Resumo - A GEOGRAFIA DAS LINHAS DE CAMINHO-DE-FERRO EM DESUSO. O QUE SE PASSA EM PORTUGAL? Ao longo dos últimos anos tem-se construído inúmeros Corredores Verdes. Recentemente o conceito adquiriu uma dimensão multifuncional, sendo usado no planeamento como uma ferramenta na preservação da qualidade ambiental da paisagem, bem como na estruturação de recursos ligados ao lazer, ou mesmo constituindo uma parte significativa no planeamento de transportes em áreas urbanas. Este artigo analisa as formas como as vias de caminho-de-ferro desactivadas podem ser uma parte integrante do planeamento de Corredores Verdes. Primeiramente, faz-se uma abordagem ao conceito de Corredor Verde e à sua história evolutiva. De seguida, apresenta-se uma breve resenha da história dos

1 A preliminary version of this article, entitled "A Requalificação de Caminhos-de-Ferro Desactivados: o caso português", was presented at the I Seminário IberoAmericano de Vias Verdes, in Santa Cruz de la Sierra, Bolívia.

2 Researcher in the Núcleo de Investigação em Geografia e Planeamento of the University of Minho, Lecturer in the Geography Departement; Social Sciences Institut, University of Minho, Campus de Azurém; Guimarães, Portugal; j.sarmento@geografia.uminho.pt 
caminhos-de-ferro em Portugal e analisa-se a situação presente no país em relação às linhas de caminho-de-ferro nas quais já não há circulação ferroviária. Finalmente, explora-se detalhadamente a primeira ciclovia construída em Portugal, aproveitando uma linha de caminho-de-ferro: a ciclovia entre Guimarães e Fafe, no Noroeste do país.

Palavras chave: Corredores Verdes, Ciclovias, Caminhos de Ferro em desuso, Planeamento de Transportes e Lazer.

\section{INTRODUCTION}

To make a greenway is to make a community

(LiTtLe, 1990)

Although greenways have been established for a number of years throughout the world, the concept has only recently acquired a multifunctional dimension, being now used by planners as a tool for preserving the environmental qualities of landscapes, as well as to structure leisure facilities and even to be a significant part of transport planning. This paper results of an investigation of the ways in which disused railways can be an integral part of greenway planning.

\section{THE GREENWAY IDEA}

The study of Greenways has been identified as a current trend in the research and professional work among landscape planners and designers (Little, 1990; Fabos and Ahern, 1996; Ribeiro, 1998). In very simple terms, greenways have characteristics indicated by the two components of the word: the land has environmental quality and it provides a route, for humans, animals or a natural processes (TURNER, 1998). We may think of parks as patches and greenways as corridors. This notion implies the movement between two points and the displacement of people, animals, seeds or water (SEARNS, 1995).

\section{The evolution of Greenways}

To analyse the origins of the concept we must look back to the eighteenth century, and the establishment of the first public garden ways and parks that connected different urban spaces ${ }^{3}$. The boulevards of Paris are a superb example of urban structures which are planned for the pleasure that travellers, rather than spectators, can take in moving along a tree lined street. The visual experience was, at that time, one of the most important elements in the conception of

3 Two thousand years ago, in the ancient world of Babylon and Egypt, avenues were made for religious processions, military parades, coronations and burials. 
greenways. Later, in the second half of the nineteenth century, Frederick Law Olmsted (1822-1903) developed the concept to include aspects such as environmental protection, preservation and conservation of heritage and landscape resources, which have much in common with the modern definition of Greenways. In 1860, Olmsted proposed the first landscape pleasure drives for horsedrawn carriages - parkways ${ }^{4}$ - inspired by the European boulevards.

As a consequence of the high urban densities and sometimes resultant poor living conditions of cities in the late nineteenth century, Ebenezer Howard (1850-1928), in his conception of Garden Cities ${ }^{5}$, developed the idea of Greenbelt, a buffer zone of rural, forest or park areas, surrounding the urban spaces (HALL and WARD, 1998). At about the same time, park systems became important as tools of planning. They differ from park belts in the way they run through the middle of urban areas, while the former are just rings of recreational open space located on the fringes of urban areas. The first and most famous example is 'The Emerald Necklace' - the system of parks in Boston - designed by Olmsted. It was based on a linear system of green areas along water lines and swamps, which aimed at tackling issues such as water pollution, flood control, urban sprawl, together with providing recreation and leisure spaces (HALL and WARD, 1998; TURNER, 1998). Park systems connect watercourses to mountain or hillcrests, or other corridors in urban areas closed to motor traffic.

Patrick Geddes (1854-1932), an early twentieth century regional planner, introduced the concept of the natural region in planning, by arguing that any planning attempt should start with a survey of the existing resources of that natural region, the human responses to it, and the resulting complexities of the cultural landscape (HALL, 1988). His work has been most influential on the evolution of landscape planning, and even in the idea of greenways.

In the second half of the twentieth century, due to a deeper environmental awareness, greenways regarded as linear zones with a special focus on environmental objectives started to be developed. Not only numerous green trails along lines of opportunity were built throughout the United States and Central and Northern Europe, but also many greenways including objectives such as biodiversity, habitat protection, historical preservation, erosion control, flood hazard reduction, water and air quality improvement, education and interpretation, scenic protection and recreational provision.

In the 1980s, a new phase in the history of the concept of greenway emerged. Not only were greenways aimed at improving urban leisure spaces

\footnotetext{
4 Parkway, the American development of boulevard, was originally a tree-lined curvaceous boulevard.

5 At the same time, although possibly independently, Arturo Soria y Mata (1844-1920), a Spanish engineer, argued for the construction of a linear city (La Cuidad Lineal), which would allow each family to have a house and a piece of land (Para cada familia una casa, en cada casa una huerta y un jardin). His idea of a linear Garden City was based on a tramway line or light rail system running radially out from a city. From the 48 kilometres of planned linear city, only five were ever built, which in the mean time were "swallowed" by the growth of Madrid.
} 
and preserving the visual quality of urban landscapes, but, as multi-purpose spaces, they included dimensions such as environmental conservation, heritage preservation, protection of cultural diversity and public participation in the initiatives and strategies of development and landscape conservation (FABOS and AHERN, 1996).

Recently, the development of greenway planning is tightly connected with the importance of sustainable development and with the need for sustainable transportation, especially in urban areas. Initiatives such as Car Free Cities (started in 1994), Energie Cités (aiming at protecting the environment in urban areas by rationalising the use of energy), Cities for Cyclists (created in 1991), the European Chart for Sustainable Cities (attempting to promote Agenda 21 at local level) and Eurovelo (project that tries to establish 12 cyclist routes across Europe), are just some of the dimensions of the Greenway movement in Europe. In the United States, the initiative Rails-to-Trails, has achieved the opening of an impressive 16,000 km of trails from 1986 to 1998. In 1998, the European Greenways Association was founded in Belgium, which aimed to establish greenways throughout Europe as well as exchanging knowledge and experiences from different countries that had already begun this process. In Belgium, for example, since the mid 1990s that disused railways are being transformed into greenways, focusing primarily on tourism. The greenway network of the programme RAVeL (Réseau Autonome de Voies Lentes), based on disused railways, pathways and canals, is currently $900 \mathrm{~km}$ long (EUROPEAN GREENWAY Association, 2000). In Spain a survey conducted in 1993 identified and analysed in detail 98 disused railways representing a total of $5764 \mathrm{~km}$, including 954 stations and wayside stations, 501 tunnels and 1070 bridges or viaducts, plus 89 old mining railways adding $1920 \mathrm{~km}$ to the total length of abandoned rails. Presently, over $1000 \mathrm{~km}$ of these railways have been converted into greenways (40 Vias Verdes). Examples from France, the United Kingdom and Luxembourg would only add to the list of cases illustrating the emphasis on reusing abandoned railways for leisure and transportation and underlying the economic and social benefits of such developments (EUROPEAN GrEENWAY Association, 2000).

\section{Greenways in Portugal}

The history of greenway planning in Portugal is relatively recent. The most inspiring visions related to greenway planning can be traced back to DE GRÖER's Lisbon Urban Master Plan (1948), in which a real concern with the urban development of the capital was illustrated, by attempting to confine the growth of Lisbon through a green rural belt. The Public Works' minister Duarte Pacheco (1900-1943) also had an important role, by deciding to plan the Monsanto Park and the Jamor Valley in Lisbon, working closely with Keil do Amaral (1910-1975) and Francisco Caldeira Cabral (1908-1992). Cabral developed and

implemented the concept of continuum natural, and influenced Gonçalo Ribeiro 
Telles, the prominent figure in the last 30 years to support the ideas of greenways and of a sustainable urban environment, by linking green urban systems with the surrounding rural landscape. He co-ordinated the team that prepared the Green Plan for Lisbon in 1994, based the concept of belt and radial corridors supported by ecological systems and historic/cultural resources. Despite the remarkable work of these people, very little has been achieved on the ground. The connection between the parks Eduardo VII and Monsanto, an integral part of the Ecological Structure of Lisbon,proposed several decades ago by Ribeiro Telles, has not yet been completed (MAGALHÃES, 2001).

In 1982 and 1983, the legal instruments created for the development of the Municipal Master Plans (PDM), called for zoning and policies on land use planning, networks of infrastructure, regulation of urban construction activities and for a financial plan. The National Agriculture Reserve (RAN) and the National Ecological Reserve (REN), together with the Protected Areas for Nature Conservation (1976), became the foundation for protecting green spaces and developing regional greenway networks (RibeIRo, 1998). More recently, people like J. Reis Machado and T. Andresen, influenced by Julius Fabos and Jack Ahern, from Massachusetts University, Amherst, have been developing and supervising a series of works and projects about greenways focusing particularly on the Greater Metropolitan Area of Lisbon.

Following the international trend of the last decades concerning the building of greenways, cycleways and pathways, both urban, suburban or rural, Portugal has been developing, with a significant time lag, a series of unconnected infrastructures, and celebrating significant events, in an attempt to catch up with a supposedly more ecologically sustainable development. At a national level, the vast majority of cities that have joined the POLIS ${ }^{6}$ programme, an urban re-qualification programme aiming at improving the environmental quality of cities, include cycleways. A few examples are the cities and towns of Cacém, Porto, Viana do Castelo, Vila Nova de Gaia and Viseu.

Joining the European Car Free Day since 2000 seems to demonstrate that politicians and the public at large are interested in sustainable modes of transport and concerned with the ways in which urban areas are developing. In 2000, 7 cities joined the programme, while in 2001 the figure increased to 51 and in 2002 it reached 63 cities and towns. The initiative aims to raise people's awareness for problems such as urban air quality, noise pollution and traffic congestion. Nevertheless, the day after the celebration of the European Day, life goes on as before, with very few indications of the weakening domination of the private motorcar in urban areas in Portugal.

At a local level, there is a plan to build a cycle network with a length of 238,8 kilometres in Lisbon (DA MATA, 2000). The network includes 20 cycleways of which five are already being developed. The implementation of further sections is proving to be very difficult due to different political agendas for the

6 Programa de Requalificação Urbana e Valorização Ambiental de Cidades. 
planning and development of the city. Also at a local level, the city of Aveiro has been a pioneer in Portugal in implementing the system of BUGAS (Aveiro Free Use Urban Bicycle), which allows people to use free bicycles within the city centre, in a similar fashion to the schemes in place in Amsterdam, Copenhagen, Helsinki or Portland. So far, a corresponding decrease in the use of motorcars due to this development is not evident.

The rationale behind the building of these cycleways is closely connected to the existence of a fashionable "cycling climate". Having a bicycle and the 'appropriate' equipment is trendy. Unfortunately this "cycling climate" does not include and/or reflect a positive attitude towards cyclists, especially from other road users. Together with this fashion, in the run-up to municipal elections, many towns and cities take the opportunity to inaugurate rotundas and fountains, cycleways and pedestrian walkways.

Despite these developments, the integration of cycleways and pedestrian zones in a serious and comprehensive policy of sustainable transport development or in a global plan for improving urban quality is missing. Planning for cycling and pedestrian movement in Portugal is underdeveloped (BALSAS, 2001). At the same time, Portugal is one of the European countries where the bicycle is less important as a regular transport mode. In 1995, on average, Portuguese cycled $35 \mathrm{~km}$ per year, only higher than the $24 \mathrm{~km}$ of the Spanish, but significantly lower than the Irish $(228 \mathrm{~km})$, Danish $(958 \mathrm{~km})$ or Dutch $(1019 \mathrm{~km})$ (European Commission, 2000: 20). Car ownership in Portugal has risen from 315 vehicles per thousand inhabitants in 1993 to 500 vehicles in 2000, and investment in road infrastructures has been significantly higher than that invested in railways. Paraphrasing HaLl (1988), while this takes place, the City on the Highway is winning out over the traditionally structured Transit City.

\section{THE RAILWAY NETWORK IN PORTUGAL}

The Portuguese railway network began to be built late and its pace of development was slow (ALEGRIA, 1990). In 1856 the first railway opened, between Lisbon and Carregado (36 km), built by the Companhia Central e Peninsular dos Caminhos de Ferro em Portugal. In that same year, there were $489 \mathrm{~km}$ of railways in Spain and 12,318 km in the United Kingdom already. Even considering the number of inhabitants and the area of each of these countries, Portugal never managed to recover from the late start (AlEgRIA, 1990). In 1910, the railway network was $2898 \mathrm{~km}$, connecting the main urban centres of the country. During the next 60 years, railway had a profound impact on the country, contributing to the development of various aspects of the economy, society and culture of Portugal, and to the construction and transformation of a unique cultural landscape, especially in the more remote and inland regions and areas.

Between the mid 1980s and 1990, as a result of the strong competition of public and private road transportation, and especially due to the investment on 
road construction together with the lack of investment in the modernisation of railways and associated equipment, several railways closed down (Table 1). In most cases, alternative transportation was provided by bus. In 1997, the Portuguese Railway Company (CP) was divided in two. One of the companies, $\mathrm{CP}$, is nowadays responsible for the operation of traffic, while the other, REFER (created by the Decree-Law 104/97 of $29^{\text {th }}$ April), is responsible for the construction and management of the railways. In 2000, a unit to manage the disused railways (tracks and built heritage) was created within REFER (Unidade de Gestão do Património Desactivado). At the same time, while the population of Portugal is increasingly concentrated in urban, coastal areas, the debates surrounding the railway network in Portugal are centred on high-speed trains and the TGV, and on the connection between this coastal network and the Spanish and European Rail Network. The value of the numerous closed railways in rural and more remote areas of the country is only discussed in brief newspaper articles, and always from the point of view of its heritage or tourist potential. It is rarely assumed that these railways may act as instruments that can mitigate, within a coherent strategy, the uneven territorial development of Portugal.

\section{The use of 'old' railways}

The $733 \mathrm{~km}$ of railways that are not in use any longer are not totally abandoned. Many have been appropriated by local people and are used as alternative roads or paths, in daily movements, to access fields, to shorten distances, or just as safer and quieter ways ${ }^{7}$. Hence, railways in disuse do not necessarily mean abandoned railways, since they may still have an important role in the transportation of people and goods.

Some disused railways have been used on a non-regular basis by groups of people fascinated by trains and railways, who organise tours in new or old trains. The company Graham Tours has been operating some tours in the Alentejo railway, between Beja and Moura, crossing the extraordinary bridge over the river Guadiana. The English railway enthusiasts Portuguese Traction Group also organise, without any regularity, "historic journeys". In fact, for the past five years, the use of railways for touristical purposes using new or historicold trains has grown immensely in Portugal, especially in the railways of Douro, Corgo and Tua, all in the north of the country. These initiatives result from an agreement between SPIDOURo (a society of companies that aims at promoting the regions of Douro and Trás-os-Montes) and CP, celebrated in 2000. The latter company has provided a steam engine built in 1925 and a diesel one from 1967

7 Interesting examples of the appropriation of disused railways by local people are found in many countries of Central and South America, notably in Brazil (17,000 kilometres of disused railways) and Nicaragua, where ingenious gadgets are manually constructed to circulate on the rails, in order to transport fruits, vegetables, and so on, from plantations to the villages (VIAS VERDES, 2002). 
Table 1 - Disused Railways in Portugal (2002).

Quadro 1 - Linhas Ferroviárias em Desuso em Portugal (2002).

\begin{tabular}{|c|c|c|c|}
\hline Railway & Section & $\begin{array}{c}\text { Dismantling } \\
\text { year }\end{array}$ & \begin{tabular}{|c|}
$\begin{array}{c}\text { Length } \\
(\mathrm{km})\end{array}$ \\
\end{tabular} \\
\hline Minho & Valença-Monção & 1990 & 15 \\
\hline Minho & Guimarães-Fafe & 1986 & 22 \\
\hline Porto-Póvoa and Famalicão & Póvoa-Famalicão & 1990 & p \\
\hline Tâmega & Amarante-Arco de Baúlhe & 1990 & 39 \\
\hline Corgo & Vila Real-Chaves & 1990 & 7. \\
\hline Tua & Carvalhæ্si-Bragnça & 1990 & 75.6 \\
\hline Sabor & Pocinho-Dua\$grejas & 1989 & 105. \\
\hline Douro & Pocinho-Barca D'Alva & 1990 & 2. \\
\hline Vouga & Sernada-立seu & 183 & 79 \\
\hline \multirow[t]{2}{*}{ Dão } & Viseu-Santa Comba Dão & 1983 & 50 \\
\hline & Pinhal Novo-Motrijo & 189 & 11 \\
\hline \multirow[t]{3}{*}{ Montemor-o-Novo branch line } & Montemor-o-Novo - Torre da Ga & lanha & 87 \\
\hline & Évora-Mora & 1987 & 60 \\
\hline & Évora-Reguengos de Monsaraz & 1990 & 40 \\
\hline South and Southeast & Estremoz-Vila Viçosa & 19 & 80 \\
\hline Southeast & Beja-Moura & 1989 & 59 \\
\hline Private & Mina de S. Dogmís-Pomarão & 1967 & 18 \\
\hline \multicolumn{3}{|l|}{ Total } & 733 \\
\hline
\end{tabular}

SOURCE : compiled from various documents.

for the Douro railway, and an early diesel engine for the railway of Corgo. The establishment of these historic train routes has been a success in terms of the number of tourists, which has been growing significantly: 702 in 1999, 2615 in 2000, 4580 in 2001 and an estimated 8000 for 2002 (SPIDOuRo, 2001).

On several sections of disused railways, CP and later REFER, have removed the rails, and usage by old trains is no longer possible. In other sections where rails were left, such as those between Amarante and Arco de Baúlhe (39 km Tâmega railway), Vila Real and Abambres (3,7 km - Corgo railway), Pocinho and Barca d'Alva (28 km - Douro railway) and Carvalhais and Sendas $(38,7 \mathrm{~km}$ - Tua railway), it would still be possible to establish the circulation of tourist trains. The Tâmega railway is a good example whereby substituting some sleepers and correcting the geometry of the rails, old trains not exceeding $30 \mathrm{~km}$ per hour could circulate. The costs of such works are significant, and it is not likely that REFER will opt for such developments.

Another way of using railways can be found in the Tua railway, between Mirandela and Carvalhais. In June 1995, five years after the closing down of the railway, the company Metro de Mirandela started to operate modern light trains on the $4,1 \mathrm{~km}$ that separate Mirandela and Carvalhais. The success of this initia- 
tive resulted in the operation of these type of trains on the entire length of track between Tua and Mirandela, from July 2001 onwards. Soon the section between Régua and Vila Real will have a similar operation (SPIDOURO, 2002).

\section{2. 'Rails for Trails'}

An alternative way of approaching disused railways is to transform them into greenways, under different denominations such as cycleways, pathways, tracks and other leisure paths, ecological ways, and so on, as seen above from the North American and European experience. REFER, in conjunction with several local authorities is attempting to design and conduct a series of redevelopment projects on several disused railways, in a vision which is named a network of eco-ways (Sistema Nacional de Pistas Verdes ou Ecopistas). RefER's strategy is based on the concession, up to a maximum of 25 years, of the railways platforms to local authorities. The rights to use the railways are given to the local authorities, while the property remains in the hands of REFER. While the projects to recover the railways and the built heritage are REFER's responsibility, local authorities must pay an annual fee per kilometre of railway (250 Euros), and take on all the construction work ${ }^{8}$.

According to REFER's own plan, in the first phase of the eco-ways network (total of 119,7 km), 6 projects are included: Valença-Monção $(15 \mathrm{~km})$; PóvoaFamalicão (3 km); Torre da Gadanha-Montemor-o-Novo (13 km); Santa Comba Dão-Naguselas (9,7 km); Montijo-Pinhal Novo (11 km); and Évora-Reguengos de Monsaraz (40 km). Recently, an agreement between REFER and the local authorities of Valença and Monção has been signed, in order to create the Minho River Eco-Way (Ecopista do Rio Minho), with a length of about $14 \mathrm{~km}$. REFER has already completed the project of landscape architecture (REFER, 2002), and now it is in the hands of both municipalities to obtain 162000 euros to finance the project.

The local authorities of Chaves, Vila Pouca de Aguiar and Vila Real have also signed a protocol (1 $3^{\text {th }}$ March 2002) aimed at creating a cycleway along the railway of Corgo, with the length of about $17 \mathrm{~km}$. However, the pioneer project in Portugal using a disused railway for the construction of a $6 \mathrm{~km}$ long cycleway took place before the existence of REFER, in the municipality of Fafe, open in 1996, and which will be discussed in a later section.

In a similar fashion to the planning and building of the railways in Portugal, done without a clear, global and integrated plan (AlEGRIA, 1990), the construction of a network of eco-ways or greenways, according to REFER's plan, is far from being a coherent and sustainable development strategy. This line of argument can be organised according to four different dimensions.

8 At international standards, the cost of transforming rails to trails average $\$ 30,000 / \mathrm{km}$, excluding special bridges or viaducts (VíAs VERDES, 2002). 
Firstly, this supposed network of greenways has not been thought out in order to be articulated with other networks already existent, such as NATURA 2000 (EuRopean COMmission 92/34), the protected areas network, RAN and REN, among others. Greenways should be understood as something more than linear spaces of 3 or $4 \mathrm{~m}$ width. The planning of a greenway must relate to the wider regional context or to the system in which the greenway is going to be in. In a sense, disused railways are considered biologic reserves, since the drainage characteristics they present allow and attract different species of flora and fauna. Its transformation requires environmental studies that go well beyond projects of landscape architecture, even if these are of a high standard, such as the one produced by REFER for the Ecopista do Rio Minho (REFER, 2002).

Secondly, there has been a lack of public consultation and participation in the whole process of the planning and implementation of greenways. We cannot neglect the short history and tradition of public participation in the planning and decision-making process in Portugal. The public is not sensitive to debates and discussions about landscape transformation, to express opinions and make suggestions about different development scenarios. On the one hand, the lack of a culture of consensus formation may be responsible for the deficit of participatory planning. On the other hand, it is up to institutions such as REFER and local authorities to ensure that the territorial dynamics to be put in place are discussed with the society at large. REFER has been establishing protocols with several local authorities which do very little beyond applying for European funds to carry out what has been already established by the former entity. According to FLINK and SEARNS (1993: 18) "In most successful greenways, local residents assisted in the planning and decision-making progress". The simple question that has not yet been formulated in the context of eco-ways is "what do people - local communities and visitors - wish?"

Thirdly, the lack of voluntary groups, local associations or groups of individuals that are made responsible for the safety, management and maintenance of certain aspects of the greenways, may certainly result in the neglect and mismanagement of the greenway after its opening (see example of the cycle way between Guimarães and Fafe). In the words of FLINK and SEARNS (1993: 292) "Good greenway maintenance begins with proper planning...".

Lastly, the development of a greenway network in Portugal, with its links with the European network of greenways is totally disconnected from a national strategy of developing the use of alternative modes of transport such as the bicycle. The sustainability of a network of greenways can only exist if there is a clear policy and coherent strategy for urban, suburban and rural transport system, framed within the social, cultural and economical established goals. Presently a panoply of disconnected planning measures are in place, such as the already mentioned PoLis programme, which aims at a beautification of parts of the towns and cities without proper articulation with the surrounding environments. Within these programmes, greenways are only a loose part of an unclear strategy of urban and regional planning, in a country where sustainable transport planning is little more than the celebration of the European Car Free Day. 


\section{THE CYCLEWAY BETWEEN GUIMARÃES AND FAFE}

Good design for cycling is significantly more difficult than good design for motor vehicles.

(TURNER, 1998: 335)

The railway between Guimarães and Fafe, covering a distance of $22 \mathrm{~km}$, was built by the Companhia do Caminho de Ferro de Guimarães between 1903 and 1907. Until the 1980s, the train was one of the most important transport modes in the region, connecting Porto to Trofa, Guimarães and Fafe. The decline of the train resulted in the closing down of the section between Guimarães and Fafe in 1986. For about 10 years (1986-1996), the inhabitants neighbouring the railway appropriated this canal to shorten their daily journeys. In 1996, as a result of an initiative of the Fafe local authority, a cycleway (pista de cicloturismo) was built, with an approximate length of $6 \mathrm{~km}$, connecting Foz to Fareja, two civil parishes of the municipality of Fafe (fig. 1). Three years later the municipality of Guimarães opened a cycleway between Fareja and Devesa, completing an inter-municipal cycleway by redeveloping the disused railway between Guimarães and Fafe (SARMENTO and MOURÃO, in print).

Having a length of $14,1 \mathrm{~km}$, the cycleway starts (or ends) in the parish of Mesão Frio, about $3 \mathrm{~km}$ from the centre of Guimarães and ends (or starts) in Foz, about $1 \mathrm{~km}$ from the centre of Fafe (fig. 1). Thus, the cycleway connects the peripheries of these two cities and not the centres. Numerous roads intersect the cycleway, allowing for people to enter and exit the cycleway at various points, which is very positive since the areas crossed by the cycleway are highly populated. Notwithstanding this, not all of these entry and exit points are signposted.

Although the length of the cycleway is relatively short it crosses very diverse types of landscapes. In the municipality of Guimarães (pop. 161630 inhabitants; $627 \mathrm{inhab} / \mathrm{km}^{2}$ ), we find densely populated areas (Paçô Vieira - Infantas) and a mix character of urban, suburban and rural spaces (Devesa - Paçô Vieira). In the municipality of Fafe (pop. 49010 inhabitants; $224 \mathrm{inhab} / \mathrm{km}^{2}$ ), the cycleway mostly crosses rural areas of agriculture, forestry and pastures (Vale do Areeiro Fareja - Cepães - Bouças). Between Agrela and Foz, nearer to Fafe again we encouter a suburban type of landscape. For about $2,5 \mathrm{~km}$, the railway follows the river Vizela, giving the route a pleasurable scenery and conferring an extra sense of linearity and movement to the cycleway.

There are also some important heritage-buildings along the route, such as the tunnel of Paçô Vieira, the bridge over the river Vizela and three waysidestations. The wayside-station of Paçô Vieira is abandoned, and in an advanced stage of degradation. Beside the building, there is also an old water reservoir. In the local authority's plan for the cycleway it is mentioned that this building would be renovated and a rest area with a bar would be built (CÂMARA MUNICIPAL De Guimarães, 1997). The wayside-station of Fareja was converted into a shelter, including two benches. It is the only place along the $14 \mathrm{~km}$ of the 


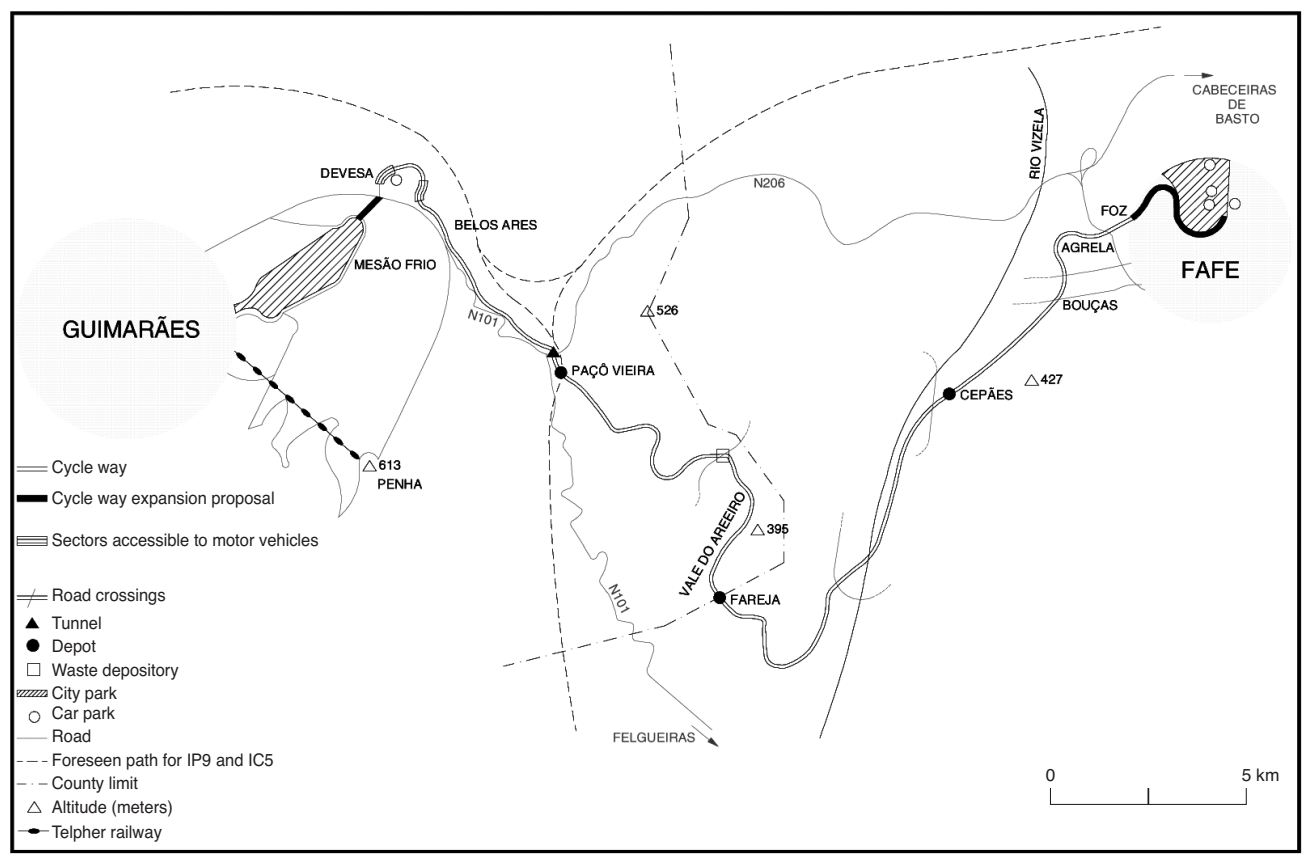

Figure 1 - The cycleway between Guimarães and Fafe (2001).

Figura 1 - A Ciclovia entre Guimarães e Fafe (2001).

Source: SARMENTO and MOURÃo (in print).

cycle way where one can stop, sit down, and take shelter. The third wayside station is in Cepães, and has been converted into a café and base for a local association. It caters mainly to the local population needs and although it was not rebuilt in connection with the cycleway, people cycling or walking along the way frequently use it.

There are two examples that illustrate quite well the fact that the cycleway was not built with the involvement of local population and that there are conflicts between the existence of this infrastructure and the needs and desires of local people. In January 2001, as a result of the harsh winter, the conservation of the pavement was damaged in certain areas. Land slides, movement of stones and mud and cracks on the pavement made the cycleway impassable at certain points. The local authority could not respond quickly enough to these problems due to human and financial resource constraints, since there were more urgent problems and situations in the municipality to be solved. For several months the situation remained as described. As a consequence of not being involved in the cycleway project, the public did not react and no local support was gathered in order to solve this specific problem. Several studies have already shown that 
engaging the public in a meaningful way in greenway and park planning "can lead to greater sense of ownership, stewardship, and community" (KAPLAN, KAPLAN and RYAN, 1998: 123). Local non-governmental agencies and grassroot groups can be important as actors and guardians who care for nature, and other locally implemented projects.

Another example of the lack of public support for the cycleway, concerns its use by motor vehicles. The side protections of the cycleway are metal rails just like those used on roads and motorways. Their purpose is not to ensure cyclists safety, but to prevent motor vehicles from entering the cycleway, especially where there are intersections with other roads. The existent protection in the 2$4 \mathrm{~m}$ high slopes is minimal (SARMEnTO and Mourão, in print). There are also two other types of protection that aim to impede motor vehicles on the cycleway, which are metal bullets of about $60 \mathrm{~cm}$ high in Fafe and metal globes of about $30 \mathrm{~cm}$ height in Guimarães. In several places these bullets have been removed so that motor vehicles can enter the cycleway. As a direct result of these conflicts a transformation of a section of the cycleway has taken place. In Belos Ares, near the town of Guimarães, the cycleway was enlarged to double its width and divided in two, separating bicycles and people from a one-way motor traffic road.

Transforming a railway into a cycle-way does not automatically create a green-way. There are several characteristics of this cycleway, which depart from the idea of a greenway, such as the environmental dimension, the aesthetics, and the continuity of the way. The environmental dimension includes aspects such as the discharge of effluents into the cycleway, which originates from, among others, an open sky sewer for about 500 metres. The existence of a dumping area next to the cycleway and domestic waste on the cycleway, especially between Belos Ares and Paçô Vieira, also contributes to this problem.

Despite the quality of the landscape along the cycleway being generally attractive, representing quite well the rural diffused patterns of landscapes in the lower Minho and the Ave valley, there is an inadequacy of scale and in the types of material used along the cycleway. These elements, namely the side protection barriers, the signposts, the bullets that attempt to prevent motor vehicles to circulate and the type of pavement, should not reflect the aspect, dimension or types of materials used standardly on roads. A specific image related to the cycleway should be adopted, through a study of shapes, dimension, design, materials, colour, and so on, of all elements in place. Road signs for people that walk at $4 \mathrm{~km}$ per hour, or cycle at $15 \mathrm{~km}$ per hour must be distinct from those that we encounter when travelling at $120 \mathrm{~km}$ per hour on a motorway.

The idea of a continuum associated with a greenway is diminished in several places, not only due to the fact that motor vehicles use the cycleway, but also as a result of the numerous roads crossing the cycleway. More important is the fact that both ends of the cycleway have no continuity. In Guimarães, connecting the end of the cycleway with the urban park involves the task of 
finding a solution to the $500 \mathrm{~m}$ that separate them. The building of a tunnel, given as a solution in the planning project of the cycleway (CÂMARA MUNICIPAL DE GUIMARÃES, 1997), would be the best option. Linking the cycleway with the urban park and the cable car near the city centre (where people can take their bicycles up to the mountain of Penha free of charge) should be a priority. It is also important to mention that there is still a section of about $3 \mathrm{~km}$ of old railway, between the cable car and an important historic building next to the urban park that is abandoned, that should be turned into a cycleway. Unfortunately, there is a plan to convert this section of railway into another urban bypass.

The terminus of the cycleway in Fafe is nearer to the centre than in the case of Guimarães. At present the planners of the local authority of Fafe are revising the spatial organisation of the urban park. A cycleway should be built for about 250m including a bridge going over the National Road 206, in order to connect the park to the existent cycleway. The impact of the construction of new roads, such as the IP9 and IC5 (connecting Guimarães to Felgueiras, and Guimarães to Fafe), should also be assessed, especially between Mesão Frio and Paçô Vieira. If more physical barriers are created, resulting in more interruptions, the creation of a greenway will be more difficult. A fundamental dimension of greenways is the perception of continuity, being that of a road, a path, a river or even a story.

\section{FINAL NOTES}

Experiences in the United States and European countries illustrate that the principal use that people give to greenways is leisure. Nevertheless, paths between urban and suburban areas can be used as transportation infrastructure and be important in commuting. In Portugal, a country with few traditions in sustainable planning, converting a disused railway into a cycleway can be understood as an extremely positive development. However, the experience of the cycleway Guimarães-Fafe illustrates that future cycleways should be carefully planned and should include the participation of local people in all development stages. No matter which development takes place, the cycleway cannot exist in a 'healthy' way without the participation of local people. So far, this involvement has not taken place, therefore putting the management, care and respect for the fundamental dimensions of the greenway in jeopardy. Planning, in the commonor-garden sense, means an orderly scheme of action to achieve stated objectives in the light of known constraints. Planning is just what this is not.

A surface of asphalt and a few road signs are a long way from transforming the future eco-ways (seen through their projects and the experience of Guimarães-Fafe) into greenways. The latter being understood as linear and continuous spaces functioning in such a way as to preserve environmental and heritage aspects and acting as leisure spaces included in wider and coherent strategies of landscape development at a local, regional and even national level. 
Greenways should be understood as systems or green webs that connect important parts or areas within urban or suburban space, such as parks, watercourses, schools, and so on, and not start and lead nowhere. Linkage is the key that is not evident in the cycleway between Guimarães and Fafe.

Two distinct questions close this paper leaving room for controversy.

Firstly, at the same time as the development of eco-ways is taking place (mimicking the general North American and European experience), the European Commission's White Paper on Transport (European Commission, 2001: 26) defends that "what is needed is, therefore, a veritable cultural revolution to make rail transport, once again, competitive enough to remain one of the leading players in the transport system in the enlarged Europe".

Secondly, and following TURNER's (1998) ideas, greenways need to be red, blue, yellow, brown, purple, white and green. To defend this 'harlequin space' means that greenways should be made in different hues, some appealing to emotions, others to the mind, others to the imagination, or being exciting, having distinct characters. In TURNER's own words: "planners need to shake themselves free of the idea that a strip of green joining two points on a map is, of necessity, a good thing. Too often, they become bland strips of grass, which one can walk along, but which, because they do not lead from an origin to a destination and do not have any other significant attractions, are not greenways. They are not pleasant and they are not routes. Business parks and housing projects are full of 'greenways' that do little and go nowhere, costing much" (TURNER, 1998: 151).

\section{ACKNOWLEDGEMENTS}

Special thanks to Sara Mourão and José Carlos Ferreira, for joining me in bicycle fieldtrips in Minho, and for contributing to my thinking on these topics.

\section{REFERENCES}

Alegria, F. (1990) - A Organização dos Transportes em Portugal (1850-1910). As Vias e o Tráfego. Centro de Estudos Geográficos, Lisboa.

Balsas, C. J. L. (2001) - Cidades, Peões e Bicicletas - Ensinamentos da Experiência Estrangeira. Proceedings of the VII Conferência Nacional Sobre a Qualidade do Ambiente, 18-20 Abril 2001. Universidade de Aveiro, Aveiro.

Câmara Municipal de Guimarães (1997) - Pista de Cicloturismo - Peças Escritas. Divisão de Propostas Municipais, Guimarães.

Comissão Europeia (2000) - Cidades para Bicicletas, Cidades de Futuro. Comunidades Europeias, Luxemburgo. 
Da Mata, D. D. J. C. (2000) - Rede Pedonal e de Bicicletas para Lisboa. Unpublished final year report in Landscape Architecture. Universidade Técnica de Lisboa, Lisboa.

De GröER, E. (1948) - Plano Director de Urbanização de Lisboa. Câmara Municipal de Lisboa, Lisboa.

European Commission (2001) - White Paper. European transport policy for 2010: time to decide. Commission of the European Communities, Brussels.

European Greenway Association (2000) - Guía de Buenas Práticas de Vías Verdes en Europa: ejemplo de Realizaciones Urbanas y Perurbanas. European Greenway Association, Belgium. [Available online at http://www.aevv-egwa.org].

FABos, J.; AHERn, J. (1996) - Greenways. The beginning of an International Movement. Elsevier, New York.

Flink, C. A.; Searns, R. M. (1993) - Greenways. A Guide to Planning, Design, and Development. The Conservation Fund, Island Press, Washington.

Fórum Ambiente (1999) - Triste Sina das Duas Rodas. Fórum Ambiente, 65, Dezembro.

Hall, P. (1988) - Cities of Tomorrow: an Intellectual History of Urban Planning and Design in the Twentieth Century. Blackwell, Oxford.

Hall, P.; Ward, C. (1998) - Sociable Cities. The Legacy of Ebnezer Howard. John Wiley \& Sons, Chichester.

Harnik, P. (1994) - Programa de 'Greenways' sobre los Ferrocarriles Desafectados de Servicio en Estados Unidos. Seminário Experiências de Utilización Alternativa de Infraestruturas Ferroviarias en Desuso: 'Vive la Vía'. Fundación de los Ferrocarriles Españoles.

HutT, C. (1994) - Programas Concretos de Reconversión de Ferrocarriles Británicos en Rutas Verdes. La Experiencia de Sustrans. Seminário Experiências de Utilización Alternativa de Infraestruturas Ferroviarias en Desuso: 'Vive la Vía'. Fundación de los Ferrocarriles Españoles.

Kaplan, R.; Kaplan, S.; RYAN, R. L. (1998) - With People in Mind: Design and Management of Everyday Nature. Island Press, Washington.

Lima, C. F. (s.d.) - Pequena História dos Caminhos de Ferro em Portugal. [Internet Document URL: http://apac.cp.pt/hist_cp.htm].

Little, C. E. (1990) - Greenways for America. The John Hopkins University Press, Baltimore.

Magalhães, M. R. (2001) - A Arquitectura Paisagista. Morfologia e Complexidade. Editorial Estampa, Lisboa.

PessoA, F. (2002) - Ecopista do Rio Minho. Projecto de Recuperação Paisagística da Plataforma Ferroviária desactivada entre Valença e Monção. REFER.

Ribeiro, L. P. A. F. (1998) - The Cultural Landscape and the Uniqueness of Place: A Greenway Heritage Network for Landscape Conservation of Lisbon Metropolitan Area. Unpublished Doctoral Thesis, Departament of Landscape Architecture and Regional Planning, University of Massachusetts Amherst.

Sarmento, J. C. V. (2002) - A Requalificação de Caminhos de Ferro Desactivados: o caso português. Paper presented in the I Seminário IberoAmericano de Vías Verdes, 23-26 Julio, Santa Cruz de la Sierra, Bolívia. 
Sarmento, J. C. V.; Mourão, S. M. C. (in print) - A Pista de Cicloturismo Guimarães-Fafe: Oporturnidade Perdida para a criação de um Corredor Verde?, in MACHADO, J. R. (ed.), Corredores Verdes: contributo para um ordenamento sustentável. Fundação da Faculdade de Ciências e Tecnologia, Lisboa.

SEARNS, R. M. (1995) - The evolution of greenways as an adaptive urban landscape form. Landscape and Urban Planning, 33 (1-3): 65-80.

SPIDouro (2001) - Relatório de Encerramento da Campanha dos Combóios Históricos do Douro 2001, Novembro.

Spidouro (2002) - Projecto Geral da Operação do Transporte Ferroviário em Veículos Ferroviários Ligeiros na Linha do Corgo, Abril.

Turner, T. (1998) - Landscape Planning and Environmental Impact Design (2nd ed.). UCL Press, London.

Vias Verdes (2002) - Proceedings of the I Seminario IberoAmericano de Vias Verdes - CD-Rom. Santa Cruz de la Sierra, 23-26 Julio, Bolívia. 